\title{
Rus, Russia, and Ukraine in Alternative Slavic Fantasy by English-Language Writers*
}

\author{
PART 1. MEDIEVAL RUS
}

\begin{abstract}
Larisa Fialkova
Alternativna slovanska fantazija je tu opredeljena kot fantastika (spekulativna fikcija), ki so jo avtorji angleškega jezika ustvarili na podlagi resnične ali domnevne slovanske folklore, ločene od slovanske fantazije same po sebi. V prispevku je poudarek na logiki interakcije med slovanskimi ljudskimi zapleti in liki z rusko in ukrajinsko zgodovino. Prvi del govori o srednjeveški Rusi v trilogijah Petra Morwooda in Katherine Arden. Drugi del, ki govori o Rusiji in Ukrajini v 19. in 20. stoletju, bo objavljen v naslednji številki revije. KLJUČNE BESEDE: Peter Morwood, Katherine Arden, alternativna in kripto zgodovina, fantazija

Alternative Slavic fantasy is defined here as fantastika (speculative fiction) created by English-language writers on the basis of real or assumed Slavic folklore, separate from Slavic fantasy per se. The focus of the current paper is the logic of interaction between Slavic folk plots and characters with Russian and Ukrainian history. The first part addresses Medieval Rus in Peter Morwood's and Katherine Arden's trilogies. The second part, which addresses Russia and Ukraine in the $19^{\text {th }}-20^{\text {th }}$ centuries will be published in the next issue of the journal.

KEYWORDS: Peter Morwood, Katherine Arden, alternative and crypto history, fantasy
\end{abstract}

\section{INTRODUCTION}

Alternative Slavic fantasy is defined here as fantastika (speculative fiction) created by English-language writers based on real or assumed Slavic folklore, separate from Slavic fantasy per se. Starting in 1989 with the publication of Rusalka, the first part of Carolyn Janice Cherryh's The Russian trilogy, it is still underway (Cherryh 1989). This Slavic trend in English-language fantasy is under-researched. Karlijn Kitzen is the first to have explored it from a comparative perspective. Her MA thesis focuses on four female

\footnotetext{
* In 2017-18, two of my Hebrew-speaking Israeli students, Aleksis Bar Gefen and Sharon Kashro, alerted me to English-language novels based on Slavic folklore. In 2019, I received important advice from Serbian colleague Tijana Tropin, whom I met at the conference Slavic Folklore and Slavic Fantastika http://rastko.rs/ rastko/delo/16029 following my presentation. I am grateful to them all.
} 
authors: Leigh Bardugo, whom she mistakenly considers the founder of the trend, Katherine Arden, Evelyn Skye, and Emily A. Duncan. Kitzen defines the main reason for the emergence of this trend in fantastika as a need for diversity (gender, linguistic, geographic and more) among the young adults who constitute its target audience. While remaining largely unknown and mysterious, Russia's proliferation in global politics makes it a good alternative to the European Middle Ages, the traditional setting for fantasy. She addresses plots and various ways of representing Russianness, including names, language, food, clothes, folklore and history (Kitzen 2019: 13-17, 79-80). She does not, however, consult historical or folklore sources outside the novels and consequently does not address ways of manipulating history and folklore. Recently, Bogdan Trocha has addressed novels by Gaiman, Valente and Arden mainly from a rhetorical perspective. He shows different types of re-narration (e.g., partial, hybrid, didactic etc.) with a gradual pass from ornamentation to genuine interest in the content of Slavic folklore. Trocha points to combining fairy tales with history but does not address its mechanism (Trocha 2020). Manipulation with fairy tales is not in his focus either.

This paper is the continuation of my project on alternative Slavic fantasy, which was initially limited to American writers of fantastika (Fialkova 2020). Here, however, I expand it to bring in Irish fantast Peter Morwood.

In the first paper of this series, I addressed the channels through which these authors know about Slavic folklore (including formal and informal education, work experience and occasionally family stories) and how they use this knowledge in their novels. The study encompassed 18 novels by 10 writers, focusing on those by four of them: Carolyn Janice Cherryh, Leigh Bardugo, Emily A. Duncan and Naomi Novik. I chose their novels because they have one important thing in common: their imaginary worlds, sometimes with imaginary maps, have no direct links to Slavic history. Although some of their toponyms are identical to those in the real world (e.g., Kiev in Cherryh's trilogy, Kerch in that of Leigh Bardugo's trilogies, and Kalyazin in Emily Duncan's book), their literary embodiments are new. Thus, Kalyazin is featured not as a town, but as a country, a variant of Russia itself. Other toponyms, although slightly changed, remain recognisable, like Polnya and Rosya in Naomi Novik's novel. Alternatively, there are those which are completely new, such as Ravka for Russia in Bardugo's writings and Tranavia for Poland in those by Duncan. The enemies and allies in these novels are also fictional. All contain signs of estranged Slavic worlds, from the representation of language, coats of arms, architecture and personal names to clothes, food, folk characters and/or beliefs. Inaccurate representations may signal not so much a lack of knowledge as the authors' choice (Fialkova 2020: 445-447, 450, 452). In future of this series, I will discuss novels in which Slavic folk characters meet Americans, whether on Slavic or American soil.

The focus of the current paper is the logic of interaction between Slavic folk plots and characters and Russian (and, to a lesser extent, Ukrainian) history. Relevant material is abundant in the novels of Katherine Arden (2017, 2018, 2019), Orson Scott Card (Card 1999), Peter Morwood (Morwood 2016, 2016a, 2016b), Evelyn Skye (2016, 2017) and Catherynne Valente (2011). My main research questions are: (1) Which historical periods, events, and personalities do English-language writers choose for their alternative 
Slavic historical fantasy? (2) How does space correspond to time? (3) Which folk plots and characters appear in these historical fantasies, and how do they influence alternative Russian and/or Ukrainian history?

These questions are addressed in each novel. The novels are discussed according to the chronology of the historical periods and events around which their plots are built.

\section{PETER MORWOOD'S RUS/RUSSIA}

Peter Morwood was born Robert Peter Smyth in Northern Ireland in 1956. Morwood was his mother's maiden name, which he legally adopted in the 1980s. Unfortunately, my attempts to learn what enticed him to Russian folklore and Russian history met without success. Morwood's trilogy copyright dates to 1988, preceding all other English-language fantasy based on Slavic folklore, but Cherryh's first novel outstrips him in publication date. Parts of Morwood's trilogy were first published by Legend Paperbacks in 1990, 1992, and 1993 (the last was revised in 2015). There is talk of his turning his trilogy into a tetralogy with a fourth book, entitled The Blue Kremlin, but it has yet to materialise. I used electronic editions of his books, which allow me to cite exact locations for specific words and sentences rather than simply page numbers.

Morwood creates his historical fantasy by grafting history to fairy tales or vice versa. The main stories he uses are Maria Morevna, ${ }^{1}$ The Tale of Ivan Tsarevich, The Bird of Light and The Grey Wolf ${ }^{2}$ (Afanasev 1916: 78-91, 192-203; Afanasiev 1984: 300-305, 331-343; Zheleznova 1966). His choice of genre is notable, because fairy tale is far more distant from history than bylina - Russian epic poetry, but it would be a mistake to assume this choice is a sign of ignorance. Fairy tales, comical and risqué novelistic tales and byliny (sometimes spelt as byliniy ${ }^{3}$ ) are addressed, recollected and contested in the text. Either this is general (Morwood 2016: 492, 1835, 2208, 2492, 3870, 3886, 3999, 2016a: 1536, 4223-4225, 4267-4280, 2016b: 454), or specific; for example, bylina about bogatyr Svyatogor who closed himself in a coffin, or confusion between Ivan and the epic bogatyr Il'ya Muromets made by some characters (Bailey, Ivanova 1998: 12-80; Morwood 2016b: 1989-1995, 5091). Folklore for Morwood is not just a warehouse of plots and motifs but a source comparable with ancient chronicles. Both types of sources may be ascertained as right or wrong. Folktales and byliny are among 1,001 items (clear allusion to The Arabian Nights), which constitute education not only for any Tsar's son,but even for the Grey Wolf (Morwood 2016: 258, 407-408, 2016a: 1536).

\footnotetext{
1 Maria Morevna AT 552A (birds or animals as brothers-in-law, $+400_{1}+554$ grateful animals help to fulfill difficult tasks $+302_{2}$ (Death of Koshchei from a horse). Some names and motifs Morwood borrowed from the fairy tale Koshchei Bessmertnyi (Koshchei the Deathless; Morwood calls him Koshchei the Undying) (Afanasiev 1984: 295-300), AT $302_{1}+400_{1}+516$ (faithful servant).

2 AT 550 (A Firebird and The Grey Wolf). 'Grey' is the popular spelling of the color in the UK and Ireland, while in the USA 'gray' prevails. Zhar-ptitsa is more often translated as 'the Firebird' rather than 'the Bird of Light.' I use Firebird, as does Morwood.

3 I use italics when following Morwood's transliteration.
} 
Morwood's Rus, which he uses interchangeably with Russia, comprises many principalities (that of Kiev, Novgorod, Ryazan and more) with princes, whose names readers may remember from history textbooks. However, it also contains an entirely fictional state, the Independent Tsardom of Khorlov, ruled by Tsar Alexandr Andreyevich and Tsaritsa Ludmila Ivanovna. The tsardom and not the principality is important because only the Tsar's son can be a Tsarevich and thus combine within himself the famous fairy tale character Ivan Tsarevich and the quasi-historical Tsarevich Ivan. To make him more real, Morwood always uses the title 'Tsarevich' before the name and never after it, according to the historical norm rather than the folk formula. The title on the cover of the trilogy's first book is, however, Prince Ivan, and in the text 'Prince' is used interchangeably with 'Tsarevich' (Morwood 2016: 58, 72, 187, 210, 232 etc.). In the final book of the trilogy, Tatars call Ivan 'Prince' or a 'Great Prince,' although by this time he is already Tsar (Morwood 2016b: 2506-2508). The title 'Prince' thus becomes inferior.

At a time of feudal fragmentation, the small Tsardom of Khorlov, which in many ways resembles Chernigov (Morwood 2016b: 3590-3591), is vulnerable and depends heavily on strategic marriages for Tsar's three daughters, Ekaterina, Yelizaveta, and Yelena, and especially for Tsarevich Ivan, who must produce a legal heir. The Tsar's daughters are rather independent, which makes finding them husbands more problematic (Morwood 2016: 432-437), but the royal intermarriages do take place. The chosen bridegrooms are not, however, from Kievan Rus but from the magic lands.

Mirroring the Russian fairy tale Maria Morevna, the bridegrooms appear as birds (a falcon, an eagle, and a raven) and turn into men. They are Fenist Charodeyevich Sokolov, Prince of the High Mountains, Vasiliy Charodeyevich Orlov, Prince of the Wide Steppes and Mikhail Charodeyevich Voronov, Prince of the Dark Forests. Ivan marries Mar'ya Koldunovna Morevna, a woman warrior and ruler of the Independent Principality of Koldunov. Although Morwood does not translate their names, their possible English equivalents are Fenist Magicianovich Falconov, Vasiliy Magicianovich Eaglov, and Mikhail Magicianovich Ravenov. Importantly, while the fairy tale characters have neither patronymics nor surnames, Sokolov, Orlov, and Voronov are all popular Russian surnames, alluding to birds rather than fairy tales. The Grey Wolf is often referred to as Volk Volkovich, which can be translated as Wolf Wolfovich. Mar'ya Koldunovna Morevna, in my translation, becomes Maria Sorcererovna Morevna from the Independent Principality of Sorcererov. In the fairy tale, she has no patronymic, similarly to the birds. Morevna is part of her name, although its grammatical form is typical of the patronymic. ${ }^{4}$ In Morwood's trilogy, where her patronymic is Koldunovna, Morevna, is like a surname. It is important to note that patronymics are a clear indication of constructed Russianness in Cherryh's and Duncan's alternative Slavic fantasies, as well as Morwood's (Fialkova 2020: 443, 450, Morwood 2016: 202, 560, 1114, 1375). In other words, Morwood's Rus/ Russia borders on a timeless, fairytale-like world, whose rulers have dynastic ties with the royal family of the Tsardom of Khorlov.

\footnotetext{
4 The Internet has unscholarly explanations of Morevna as a patronymic, e.g., a daughter of More (Sea) or Mor (Epidemy), but these are not sufficiently based.
} 
The Rus/Russia of Morwood's novels exists in quasi-historical time. While fairy tale time is dominant in the first part of the trilogy, quasi-historical time, present from the beginning, becomes more prominent in subsequent books. It manifests in various ways, including implicit or explicit dates and events, but is not limited to them. The plot begins fifty years after the Christianisation of Novgorod (Morwood 2016: 4216). Because this was in 990-991, we may assume that Morwood's starting date is 1040 AD. It would, however, be wrong to seek consistency. Morwood's Rus/Russia mixes people and events from different periods. Prince Yuriy Vladimirovich of Kiev, ${ }^{5}$ for example, coexists with Manguyu Temir ${ }^{6}$ of the Golden Horde, the princely retinue of the Kievan Rus (i.e., druzhiny $a^{7}$ ) coincides with the Cossacks from Don, Kuban, Terek and Zaporozh'ye, ${ }^{8}$ as well as with officers of the Russian gvardia guard - guard-captain Akimov, who is Ivan's military instructor, ${ }^{9}$ is an example (Morwood 2016: 178, 328, 835-836, 1187, 4176, 4799).

In the trilogy's first book, most of the adversaries are supernatural (for example, Koshchey the Undying and Baba Yaga), and Ivan must face them largely in the fairy tale world (Morwood, 2016: 1396, 3742-3744). In the next two, however, many of his enemies are human and related to historical or, rather, to quasi-historical events. In the second book, they are Teutonic Knights who, according to Morwood, prepare for a Crusade against Rus in 1234 and ingloriously perish, falling through cracked ice on the river Nemen ${ }^{10}$ in 1235 . In the third book, they are Tatars in general, and the Great Khan Ogotai and Batu Khan in particular, who, in 1237, brings destruction to Ryazan and by 1243 to most of Rus.

Despite this apparent spatiotemporal concreteness, the events and characters in Morwood's books differ considerably from their historical prototypes. The Crusade, referred to as either Northern, Livonian or Baltic, was launched by the Livonian Brothers of the Sword (or Sword Brothers), not the Teutonic Knights. The battle, in which the heavily armed knights drown with their horses through the melting ice, in reality took place not in 1235 on the River Nemen, but in 1234 on the River Emajögi ${ }^{11}$ (Selart 2015: 135). The alliance between the Sword Brothers and the Teutonic knights did not occur until 1237, three years after the former were defeated on the Emajögi (Krivosheev, Sokolov 2012: 276). In Morwood's book, the Russian troops are led by Maria Morevna and Tsarevich Ivan. Their victory is won with the help, first, of a Grey Wolf, which saves Ivan and drives the Russians from the ice in the nick of time (Morwood 2016a: 5807-5826), and then of a Firebird, which melts the ice under the opposing army (Morwood 2016a: 5829-5839).

\footnotetext{
5 We may assume this is Yuri Dolgorukii (1090s-1157). He was the Prince of Rostov in 1125-1157 (Martin 2007: 110).

6 Mengu -Timur, khan at Sarai 1266-67-1281 (Martin 2007: 185).

7 This is Morwood's spelling of druzhina. Italics are Morwood's. The starting-point of druzhina varies according to different historical theories, from the $5 / 6^{\text {th }}$ to the $9^{\text {th }}$ centuries, to the late $12^{\text {th }}$-early $13^{\text {th }}$ centuries.

8 This is Morwood's spelling of Zaporozhian (Russian) or Zaporizhian (Ukrainian) Cossacks. Longworth starts Russian and Ukrainian Cossacks history from the $15^{\text {th }}$ century (Longworth 1970: 8).

9 Russian Imperial Guard or Leib Guard was founded by Peter the Great in 1683 (Dubeniuk 2019).

${ }_{10}$ Nemen is Morwood's spelling. This hydronym has different forms - Neman, but also Nemunas, Nioman, Nyoman, Niemen and Memel.

${ }^{11}$ Emajögi is its name in Estonian. In Russian, it is Omovzha, and in German, Embach.
} 
All the glory, however, goes to the unpleasant if pragmatic prince Alexandr Nevskiy, ${ }^{12}$ who performs no heroic deeds at all. He not only brings his own chronicler to Nemen to ensure only his exaltation, but later orders the Lavrent'skiy and Novgorod chronicles ${ }^{13}$ changed to eliminate all mention of the Firebird's role in melting the ice - and, in fact, all mention of anyone other than himself. He even changes the date of the battle to imply that his nickname 'Nevskiy' comes from a battle honour rather than a birthplace (Morwood 2016a: 5906-5907, 2016b: 4980-4987). In other words, Morwood deliberately uses the notorious manipulation, omissions, and additions of old Russian chronicles (Selart 2015: 10) as rationalisation for his historical fantasy. He doubtless knows that Prince Iaroslav Vsevolodovich led the Russian troops in 1234, whereas his 14-year-old son Alexander, although present at Omovzha/ Emajögi/Embach, performed no heroic deeds in this battle. Morwood's ironic reference to Alexander's sobriquet 'Nevsky', and to the change of dates in the chronicles hint at Alexander's future triumph over the Swedes in the battle on the River Neva in 1240, the true source of his nickname. It also implicitly points to Alexander Nevsky's victory over the Teutonic Knights in Ledovoe poboishche, the Battle on the Ice on Lake Peipus in 1242. ${ }^{14}$ In 1242, however, unlike in the 1234 battle, the ice did not crack, and the knights did not drown. In other words, by changing Sword Brothers to Teutonic knights, Iaroslav Vsevolodovich to Alexandr Nevskiy and juggling the dates, Morwood combines malen'koe ledovoe poboishche, the Small Battle on the Ice of 1234 (Krivosheev, Sokolov 2012: 274) with the famous Ledovoe poboishche, the 1242 Battle on the Ice on Lake Peipus. Another major change is Morwood's replacement of the miraculous helper. Instead of it being God, as in Novgorodskaia pervaia letopis (1950: 73), the Firebird causes the ice to melt. Supernatural help is characteristic in old chronicles. Alexander's victory over the Teutonic Knights in 1242, for example, was won with the help of God, St. Sofia, and St. Martyrs Boris and Gleb (ibid: 78). Morwood simply replaces Christian miracles with fabulous wonders.

Manipulation of the chronicles has another major impact on the trilogy: Batu Khan destroys the parchment relating the story of Ivan, thus erasing the Independent Tsardom of Khorlov and Principality of Koldunov from Russian history and sending them into fairytale land (Morwood 2016b: 6133-6139, 6178). The symbiosis of paganism and Christianity, addressed in my paper on alternative Slavic fantasy's mythological trend (Fialkova 2020: 446, 450-451, 452-453), is evident in historical fantasy, as well. In this latter case, however, it is incessantly contested by Christian priests, both Catholic and Orthodox, who may either try to supplant wizards and witches or mobilise them in a joint endeavour.

\footnotetext{
12 St. Alexandr or Alexander Nevsky (1221-1263).

${ }^{13}$ It is Morwood's spelling of Laurentian chronicle or codex, 1377, which contains Zhitie - Life of Alexander Nevsky. http://expositions.nlr.ru/LaurentianCodex/_Project/page_Show.php?list=341\&n=388. Laurential and the $1^{\text {st }}$ Novgorod chronicles https://bookree.org/reader?file=762235\&pg=70 are the earliest sources about Alexander Nevsky (last accessed 12.09.2020).

${ }_{14}$ The lake is known in Russian as Chudskoe or Pskovsko-Chudskoye ozero and, in Estonian as Peipsi-Pihva järv.
} 
Serving the Tsardom of Khorlov are both the Metropolitan Archbishop Levon Popovich and the First Minister and Court Wizard and 'long-liver' ${ }^{15}$ Dmitriy Vasil'yevich Strel'tsin, who teaches Ivan theory of government and magic skills, both perceived as obligatory for a future Tsar (Morwood 2016: 113, 264-265). Despite ongoing opposition to magic in general and to sorcerers as husbands for Ivan's sisters in particular, Levon Popovich is obliged to perform their Christian marriages (Morwood 2016: 242-247, 579-583, 1125-1128). More than that, he later has to accept, much against his will, Ivan and his sorceress wife Mar'ya Morevna as Khorlov's Tsar and Tsaritsa (Morwood 2016b: 535-590). Strel'tsin's magic of small things is in counterpoint to the high magic of the necromancer Koshchey the Undying (Morwood 2016: 104, 1475, 1483) as positive to negative, similarly to that between different types of magic in alternative Slavic mythological novels by Carolyn Cherryh and Leigh Bardugo. Education in magic includes responsibility and strictly defined wishes as precautionary measures. Loosely formulated, impolite, or excessive wishes may have unexpected and unwanted consequences, among them the cruel death of the wisher. The use of high/evil magic by positive characters is always regarded as problematic although sometimes inevitable (Fialkova 2020: 444, 446, 448; Morwood 2016: 3378-3390, 2016a: 3858-3890, 2016b: 597-598, 5800-5810).

Christianity is accepted not only in the Tsardom of Khorlov but even in Mar'ya Morevna's Independent Principality of Koldunov. Her Orthodox chaplain, the Kanonarch Protodeacon Sergey Strigunov gives up all attempts to reconcile Christianity with her magic (Morwood 2016a: 591-595). The bird-husbands of Ivan's sisters cross themselves and pray in different situations, notably when resurrecting Ivan from the dead necessitates their performing high magic/necromancy (Morwood 2016: 3361, 3390, 3469-3474, 3484).

Magic also finds its way into the citadel of Catholicism. According to Morwood, 'the papal attitude to sorcery is one of guarded approval', but in Rus it is practised without papal consent and serves as the pretext for the Crusade. Hermann von Salza, Grand Master of the Teutonic Order, ${ }^{16}$ is not only sufficiently skilled in magic to have a coffer of freely changeable size but agrees to seek help from the traitorous Baba Yaga herself. The Teuton defeat in battle is, in fact, to a large extent the result of Baba Yaga's misbehaviour with the Firebird. The Firebird takes revenge by eagerly helping Mar'ya Morevna and Ivan in cruelly eliminating Baba Yaga (Morwood 2016a: 212, 360, 1378-1389, 2062-2186, 3207-3213, 3840-3873, 4747, 5218-5230).

Magic is acquired not only through formal lessons but also through self-education reading. Brochures, manuscripts, books and libraries, therefore, feature prominently not only in the mythological trend of alternative Slavic fantasy (Fialkova 2020: 452-453), but in Morwood's historical fantasy as well. They constitute important items that can be given, inherited, stolen, fought for, resumed and/or found through intuition. Their languages and scripts require linguistic proficiency in their readers. Mar'ya Morevna's late father thus

\footnotetext{
${ }^{15}$ Long life is also characteristic of witches and wizards in mythological alternative Slavic fantasy, e.g., in the novels of Cherryh, Bardugo and Novik (Fialkova 2020: 444, 448, 453).

${ }^{16}$ Hermann von Salza (1179-1239) was indeed a Grand Master of the Teutonic Order. Unlike in Morwood's plot, however, he had no part in the 1234 Battle on the Ice (Seward 1995: 97-102).
} 
makes especially important notations in Norse runes. Another book in her library, On the Summoning of Demons, which Ivan reads on her recommendation, is oxymoronically written in supposedly ancient Hungarian penned in Old Slavonic Cyrillic script (Morwood 2016: 2792-2804, 2016a: 492-510). Ivan is also proficient in reading Latin manuscripts but cannot decipher Homer's $\mathrm{Il}^{\prime} \mathrm{yad}^{17}$ either in its original Greek or in High Church Slavonic old Glagolitic script and must rely on a Russian translation made by his late father-in-law.

The Iliad, as a source of empowerment, is depicted, with an aura of irony, as akin to magic books. In its verses, Ivan finds a description of the drink of heroes: wine mixed with resin and salt (if not directly with seawater). Surmising that only a true hero would regularly drink so disgusting a concoction, Ivan develops a taste for it, and it is this drink that he proposes to his so-called guest, Batu Khan's representative Amragan Tarkhan (noble), who is in Khorlov to demand submission to Tatars. Ivan's plan to confound Amragan with the drink fails, however, as the Tatar is clearly accustomed to it. Since this drink of heroes is, in fact, a cocktail, I suggest it is inspired by cyceon (also kykeon), the only cocktail in the Iliad, which Hecamede prepares for Nestor and Eurydemon. ${ }^{18}$ Morwood directly compares the Tsardom of Khorlov with Troy and makes use of the ethos of drinking in Homer's world, which sometimes involves doing so with the enemy, as did Achilles and Priam (Morwood 2016b: 2759-2803; Papakonstantonou 2009: 4, 13). Allusion to the Iliad is similar to that of the old chronicles, as discussed above: hinted facts overcome major alterations. Remarkably, in this quasi-Slavic historical fantasy, Morwood prefers referencing Homer's epic than he does byliny, although feasts and alcohol consumption are also prominent there (Harkins 1976).

Morwood's characters need polyglot skills not only for reading but also for oral comprehension, which is especially important in diplomacy and in the eavesdropping of scouts. The Grey Wolf (Volk Volkovich) speaks some Farsi but is helpless with Uighur and Turku-Mongol dialects (Morwood 2016b: 2117-2118). His acquaintance with Turkish and Mongol mythology is, however, sufficient for understanding its importance in magic, and he disguises himself as the Blue She-Wolf, considered sacred by Turks and Tatars, connected to the god Tengri, the Blue Sky, and ancestor of the Chinggisid lineage. Evidently, the invaders do not dare question their 'sacred ancestor's' clumsy Farsi, which helps Volk Volkovich successfully scout (Dalkesen 2017: 195; Morwood 2016b: 1296-1300, 2116-2118; Shcherbak 1993: 204, 206, 209).

Full proficiency in languages and magic is given solely to Mar'ya Morevna. She not only understands dualism (Chernobog, the Black God, versus Belobog, the White God; Erlik Khan versus Tengri as evil versus good, which some readers may also know ${ }^{19}$ ) but

\footnotetext{
17 This is Morwood's spelling of the Iliad.

18 'Therein the woman, like to the goddesses, mixed a potion for them with Pramnian wine, and on this she grated cheese of goat's milk with a brazen grater, and sprinkled thereover white barley meal; and she bade them drink, when she had made ready the potion' (Homer, XI: 618-643).

${ }^{19}$ Chernobog is very popular in alternative Slavic fantasy (Fialkova 2020: 443, 454). However, not all scholars agree that Belobog and Chernobog actually were Slavic gods and perceive them as artificial reconstructions on the basis of toponymical data and literary reminiscences (Tolstoi 1995: 151). Similarly, the dualism of Erlik Khan and Tengri is contested by many experts in ancient Turkish religion (Alici 2011: 148-151).
} 
espouses what I can only define as an alternative vision of gods. She denies the Russianness of Chernobog and the Turkishness of Erlik Khan, asserting that they are the same evil force. Similarly, she declares that Belobog, Othinn, Thorr, ${ }^{20}$ Tengri and Archangel Mikhail are simply different names for the same force of good (Morwood 2016b: 5882-5885, 6046-6049). Inborn skill in sorcery, correct upbringing by her father Koldun and serious education help Mar'ya Morevna in many areas, from acquiring help from the Firebird to mitigating the disastrous consequences of misuse of magic by the Tatars and reckless Russian amateurs. Despite all her knowledge and power, however, she is not omnipotent. While easily slaying thousands of Tatars in battle single-handedly, she cannot win the war against them or even prevent displacement of the Independent Principality of Koldunov and the Independent Tsardom of Khorlov from Rus to the Summer country in fairy tale land. Ivan's surmise that it will be the western knights rather than the Russian princes who end their quarrels in the face of invasion and unite (Morwood 2016b: 1706-1712) points to two important issues: the return to history and Morwood as an outsider. The perception of Rus as the shield of Europe, whether or not correct, is deeply etched into the collective Russian psyche. In Morwood's world, it does not exist.

\section{FROM IVAN KALITA TO DMITRY DONSKOI: KATHERINE ARDEN'S RUSSIAN HISTORICAL FANTASY}

Katherine Arden has a BA in Russian studies from Middlebury College in Vermont and spent more than a year studying in Moscow. There is additional material to each book of her Winternight Trilogy (i.e., interviews, author's notes on transliteration and her treating of history, reader's guides and glossaries) indicating the educational orientation of the author and publisher. In this material, Arden details some of her sources for Russian history and culture, including Afanasyev's collection of folktales, Linda Ivanits's Russian Folk Belief, the Domostroi, and Janet Martin's Medieval Russia (2017: 326, 327, 329, 2018 : 349-350). Contrary to Morwood, Arden does not mix different periods and events of Russian history but concentrates on the $14^{\text {th }}$ century. Following Janet Martin's textbook, she addresses rules of succession and their role in political legitimacy, the importance of the Orthodox Church in political decision-making, and Rus's relations with the Golden Horde (Martin 2007: 221).

The temporal borders of her plot start under Prince Ivan Kalita's (?-1340) ${ }^{21}$ rule in Moscow in the 1330s and end after the victory of his grandson, Prince Dmitrii Ivanovich (1350-1389), over the armies of the Golden Horde in the Battle of Kulikovo (Snipes' Field) near the River Don in 1380, a battle that gave him sobriquet Donskoi. Arden claims to have striven for accuracy, a claim which, in many aspects, can be accepted.

\footnotetext{
${ }^{20}$ Othinn and Thorr are Morwood's spelling of Odin, supreme god in the Germanic and Northern pantheon and his son, Thor.

${ }^{21}$ Kalita means 'the money-bag' in English (Martin 2007: 208). Various sources give different years for his birth - 1284, 1288, 1304 etc. (Borisov 2005: 61; Ekzempliarskii 1889: 71).
} 
She addresses the devastating plague. She knows that the Russians were forced to pay Tatars silver tribute, a shortage of which they suffered in the years preceding the Battle of Kulikovo. She is aware that rivers were used as routes to bring tribute to the Tatars and that these routes were often unsafe. Dmitrii tried to deliver tribute to Mamai in 1378-1380 but was unable to do so because of confrontations with Tatars (Arden 2019: 130-132; Martin 2007: 236-237). Arden even indicates changes she made for dramatic reasons, for example, making Prince Vladimir Andreevich of Serpukhov (1353-1410) older than Dmitrii Ivanovich, although he was, in fact, younger, and marrying him to a girl named Olga Petrovna ${ }^{22}$ (Arden 2017: 314, 2018: 349-350; Kitzen 2019: 44-46). She does not, however, address certain other, more blatant changes. Thus, Prince Oleg of Ryazan, who eventually supported Mamai in the Battle of Kulikovo, fights on the Russian side against Tatars in Arden's version of history (Arden 2019: 344-346; Martin 2007: 236).

Like Morwood, Arden combines Russian history with fairy tales, and Christianity with paganism, but in quite different ways. The Church's struggle against the old gods, whom it perceives as chyerti $^{23}$ (devils), lead to their decline. Pagan spirits starve without offerings. In their enfeebled form, they fade away, unable to defend Rus from the Tatars. For Rus to survive, there must be peace, unity and a pooling of power between Christianity and paganism.

Again, unlike Morwood, characters who originate in fairy tales (both folk and literary) are interwoven with the genealogy of historical Russian princes. An example is the family tree of Vasilisa Petrovna, the trilogy's protagonist, usually known by the gender-neutral diminutive Vasya, which signals her androgynous character, or sometimes by feminine diminutive Vasochka. Her great-grandmother is the folktale character Baba Yaga, usually portrayed as a villain or, more often, a donor. Her great grandfather is Chernomor, a positive sea-related character from Pushkin's The Tale of Tsar Saltan (Arden 2019: 368-369; Propp 2012: 156-162; Pushkin $\left.1978[1831]^{24}\right)$. Their daughter, Vasya's grandmother

\footnotetext{
${ }_{22}$ Vladimir Andreyevich the Bold, Prince of Serpukhov and Ivan Kalita's grandson, was married to Elena. However, his wife's patronymic, Olgerdovna, is phonetically close to Olga http://100.histrf.ru/commanders/ serpukhovskoy-vladimir-andreevich/ (last accessed 22.03.2021).

${ }^{23}$ Arden feels free to spell Russian names and other words as she likes. It is important to her that the words 'retain a bit of exotic flavor', be 'reasonably pronounceable and aesthetically pleasing to speakers of English' (Arden 2017: 313), although she uses them without any graphic signals, e.g., molodets, devochka, medved, domovoi, vodianoy, chyerti, Bashnya Kostei, etc. (Arden 2017: 10, 24-25, 82, 113; Arden 2018: 298). I have put Arden's spelling of Russian words in italics.

24 'Lo! The ocean swells in thunder,

Surges with a mighty roar,

Overflows a barren shore,

Leaving, wonderful to see,

Thirty stalwart knights and three,

All in mail a-gleaming bright,

Marching proudly left and right;

Each one brave beyond compare,

Tall of stature, young and fair,

All alike beyond belief,

Led by Chernomor, their chief.'

Each book or the trilogy starts with an epigraph from Pushkin.
} 
Tamara, is devastated by a love affair with the fairy tale villain Kaschei, ${ }^{25}$ and marries the widowed Grand Prince (Duke) of Moscow, Ivan Kalita. Unfortunately, there is no reliable information about Ivan Kalita's real-life second wife, Uliana, who gave birth to either one daughter (Ekzempliarskii 1889: 79-8026) or two daughters (Borisov 2005: 218-219). Arden replaces Uliana and her anonymous progeny with the fictional Tamara, her daughter Marina and five grandchildren, providing them with biographies of her choice.

Although Marina has no magic ability, she is given in marriage to a boyar, Pyotr Vladimirovich, and lives in a remote estate in the woods, thus ridding the Great Prince's palace of a witch's daughter. Marina dies giving birth to her fifth child, Vasilisa, who, as she mysteriously knows, will inherit her grandmother Tamara's magic power. Several years after Marina's death, Ivan Kalita's son, Great Prince Ivan Krasnii (1326-1359), ${ }^{27}$ relying on the advice of Aleksei, Metropolitan of Moscow (1293-1378), ${ }^{28}$ arranges two marriages. First, is that of Olga, eldest daughter of Pyotr and Marina, to Prince Vladimir Andreevich of Serpukhov. Its purpose is to prevent Vladimir from making a more politically advantageous marriage and thus neutralise his probable aspirations to rival Dmitrii Ivanovich. The second is marrying Pyotr Vladimirovich to his daughter from his first marriage, Anna. This young girl of Arden's creation is not only hated by her motherin-law but can see chyerti (devils), thus potentially damaging the reputation of Ivan Krasnii's other children and especially that of his heir. It should be noted that Vladimir Andreevich, Dmitrii Ivanovich and Anna Ivanovna, along with Pyotr and Marina's five children, are all Ivan Kalita's grandchildren, and thus cousins, making Arden's trilogy a family saga (Arden 2017: 44-46, 55-57). ${ }^{29}$

Whereas Morwood's characters often read fairy tales and byliny as part of their magic education, Arden's characters learn them in the traditional way, by hearing them, from old Marina's and her children's nanny Dunya and, later, from Vasya. Among these stories are Finist the Falcon, ${ }^{30}$ Ivan and the Gray Wolf, Firebird, Marya Morevna and especially the story of Frost or Morozko, which Dunya tells in full at the beginning of the trilogy. Dunya's story is, in fact, a combination of two of Afanasyev's versions, to which Arden makes several changes. A poor, half-orphaned girl Marfusha is sent to the winter forest by her father's wife to marry Morozko (Frost). Instead of freezing to death, as the wicked stepmother intends, she returns home with a large dowry for a human

\footnotetext{
${ }^{25}$ Cf. his name in Arden's trilogy, Kaschei the Deathless, who 'can never die' (Arden 2017: 20; 2018: 267, 323), with its version in Morwood's trilogy discussed above - Koshchei the Undying.

${ }^{26}$ Information in the note continues on page 80 after the item on Ivan Kalita.

${ }^{27}$ Ivan Krasnyi or Ivan II Ivanovich the Fair, had two sons, Dmitrii and Ivan, and a daughter, whose name is unknown (Ekzempliarskii 1889: 92). Arden calls the daughter Anna and gives her a fictional biography.

${ }_{28}$ Metropolitan Aleksii or Alexis was Ivan Kalita's godson. He became Ivan Krasnyi's adviser and, after his death, regent to his heir Dmitrii, who was still a child. Aleksii was canonised by the Russian Orthodox Church in 1448 (Martin 2007: 231; Prokhorov 1988).

${ }^{29}$ Martin, whose book is the main source of Arden's historical knowledge, mentions Vladimir Andreevich's importance, as well as neutralising possible rivals through intra-dynastic marriages, a practice which Kalita's descendants regularly implemented (2007: 211-213, 231).

${ }^{30}$ Differently from Morwood, Arden uses the transliteration Finist and not Fenist, Gray and not Grey (Arden 2017: 4).
} 
husband. The stepmother's own daughter then tries to get herself a dowry in the same way but dies in the attempt. In Dunya's story, mother and daughter are named Darya and Liza and both die. After Dunya finishes the tale, little Olga, the future princess of Serpukhov, wonders whether Marfusha indeed marries King Frost, which Dunya denies (Arden 2017: 4-9; Afanasiev 1984: 113-117; Zheleznova 1966 ${ }^{31}$ ). Taking into account Morozko's prominent place in Arden's trilogy and his union with Vasilisa by its end, it is easy to make a mistake and to perceive this fairy tale as the main source for the plot (Kitzen 2019: 50, 87-89).

Some Morozko-related motifs in Arden's trilogy do not, however, correspond to Afanasyev's folktales. The two most prominent are: (1) Anna Ivanovna's command to Vasya in the first book to bring podsnezhniki - snowdrops from the winter forest; and (2) Vasya's sexual liaison with Morozko and their prospective union in the third book. The sources of both are easily identified: Samuil Marshak's play, Twelve Months, written in 1942-1943 (Marshak 1958). ${ }^{32}$ Prior to Marshak, the same motif of flowers in winter, though with violets in place of snowdrops, is found in the Czech folktale recorded by Božena Němcová in 1857-1858, and in its Russian retelling by Nikolai Leskov in 1863. Whereas Marshak cites Slavic folk poetry as a source of his inspiration (Marshak 1958: 351), Katia Senne suggests this is mere camouflage for his familiarity with Nikolai Leskov's retelling of Němcová (Senne 2017: 230). ${ }^{33}$ In both the Czech folktale and Leskov's retelling, the young woman marries a mortal man (a farmer or peasant), who will look after the house, cow and field that she inherits from her stepmother and stepsister. In Marshak's play, however, after the month of April gives her the snowdrops, she accepts his magic ring, unaware of its association with marriage (Marshak 1958: 398-400). In Arden's book, in contrast to those by Němcová, Leskov, and Marshak, Morozko is not a month but the King of Frost and the spirit of Death Karachun. ${ }^{34}$ He cannot change places

\footnotetext{
31 The current English translation lacks the motif of marriage to Morozko as the formal pretext for the girl's banishment.

${ }^{32}$ It also became the basis for cartoons (Ivanov-Vano 1956) and a movie (Granik 1972), both of which were very popular. Marshak's play was translated into English, and cartoons and a movie with English subtitles can be found on YouTube (Marshak 2000). A movie with subtitles is at: https://www.youtube.com/watch? $\mathrm{v}=$ GbeiOMN0RMs, cartoons with subtitles are at: https://www.youtube.com/watch? $\mathrm{v}=6 \mathrm{Cy}$ omhxRhM (last accessed 12.10.2020).

${ }^{33}$ In Němcová's version of the story, a cruel step-sister, Holena, supported by her mother, sends orphaned Maruška three times to the wood in cold January weather to bring her, in turn, violets, strawberries and apples. Maruška finds twelve brother-months near a big bonfire. Taking pity on the sweet, unfortunate girl the brothers help her. So she can get what she needs, January temporarily changes place with March, then June, then September, each providing her with things they rule. Nothing, however, satisfies the greedy Holena. She puts on her fur coat and goes to the woods to find more apples, even if they are guarded in hell by the devil. Her offensive behavior irritates January, who freezes her to death. Holena's mother runs to the wood in search of her daughter, where she, too, dies. Maruška inherits their property and soon marries a nice, handsome young farmer (Němcová No Year). Leskov's version is close to the original (Leskov, No Year).

${ }^{34}$ Although Arden cites Ivanits's book as her source about Russian mythology, its subject index has neither Karachun nor Korochun (Ivanits 1989: 248). According to Valentsova, karachun/korochun/kerechun has different meanings connected to Christmas rites and beliefs, including death, unexpected death and evil spirits (Valentsova 1999: 468-469). Korochun, however, which is similar to Arden's Morozko/Karachun is, to my mind, of literary origin, for example, from Aleksei Remizov's eponymous story first published in 1906 (Remizov 2000 ), which promoted the appearance of this character in Russian fantasy.
} 
with March or April, even briefly, as they are not part of the plot. His twinbrother is the Bear, a devilish devourer who rules in Summer. To find the snowdrops, Morozko goes to the edge of his realm, which is in thaw. The situation mirrors that of Anna Ivanovna coming to the woods, led by the Bear-possessed Orthodox priest Konstantin. Before killing Anna, the Bear gives her snowdrops from the thawed earth (Arden 2017: 260, 277, 287-288). The division between Winter and Summer, Morozko and Bear contributes tension with these twins forming a unity of opposites, whose struggle is eternal. Trocha even compares them with Belobog and Chernobog (Trocha 2020: 411).

Another example of the mirroring of characters is that of Vasya and Anna Ivanovna, young, half-orphaned cousins who see chyerti. Both are perceived as witches, hated by their stepmothers, and have no interest in a dowry. The fate of both is with mythical beings: Anna as the Bear's victim, and Vasya as Morozko's lover/intimate life companion. This twinship also finds its roots in Marshak's play. Although the wicked stepmother sends the girl into the winter forest for snowdrops, the idea is not hers but that of a capricious teenage orphan queen, who promises to pay in gold for the flowers. Once she has them, it is the queen who insists on going to the wood for more. The stepdaughter refuses to show her where to find the snowdrops. The stepsister gives the queen April's wedding ring, stolen from the poor girl. The angry queen flings the ring into an icehole. At this moment of high drama, the heroine says the magic poem that April has given her for times of need. The poem functions as a charm. The ring brings them all to the clearing where the snowdrops grow and to a bear, which has just awoken. Although the stepdaughter has many fur coats from the brother-months, her bridegroom April has no need of her dowry. Needless to say, the idea of dowry never bothers the repentant queen either (Marshak 1958: 446-477).

In Anna, who is Ivan Krasnii's daughter, Arden combines the teenage orphan queen with both stepmother and stepsister. The motive of theft is bestowed on Anna Ivanovna. The object she takes from her stepdaughter is not, however, Morozko's necklace, but the wooden cross made by the Bear-possessed priest Konstantin to subdue Vasya. Naturally, the priest brings Anna to the Bear. The twinning of sister and stepmother is also reflected in Olga's belief in the words of the Bear-possessed priest. Because of this, she attempts to marry Vasya to Kasyan/Kaschei, thus banishing her witch-sister from the palace and saving her own daughter, Marya. However, the priest, who earlier took Anna to the Bear, brings Olga's Marya to Kaschei (Arden 2017: 143, 286-288, 2018: 276-277, 285-286, 314-315, 324).

Not only the Marshak-inspired characters but even the magical ring find twins in Arden's trilogy. Instead of a ring, which binds the innocent girl to April, there are magical necklaces that do the same. Arden's gender ideas, however, differ from those of Marshak. Although Morozko gives his necklace to Vasya while she is still a child, she later destroys it. Her liaison with him thus becomes her free choice. As with Morwood's characters, this is a union between two independent subjects each ruler of his/her own realm. They do not, however, wed: not because of Church refusal to perform a marriage ceremony, but because Vasya and Morozko perceive it as irrelevant. To make Vasya Morozko's equal, Arden elevates her as Baba Yaga's heir and reveals previously hidden familial 
relations to Chernomor, the sea-king, making him her great grandfather. Chernomor's blue necklace, which Vasya receives via Morozko, is simply a non-binding gift from her ancestor (Arden 2018: 291-293, 2019: 149-152, 158, 248-249, 326-327, 353-354). Other necklaces are put on women by the evil Kasyan/Kaschei to enslave them. Vasya not only manages to avoid and destroy her bridal gift from Kaschei; she also destroys that of her niece, Marya and of the ghost of her grandmother Tamara, thereby liberating both. Kaschei's necklaces are, in fact, analogues of the egg which guards Kashchei's death in Russian fairy tales. This is almost explicitly stated by comparing Tamara's jewel with the eggshell. Their multiplicity is, however, reminiscent of Voldemort's Horcruxes from J.K. Rowling's Harry Potter series (Arden 2018: 267, 273-275, 326-330).

Arden stresses that Vasya's unconventional gender behaviour is in direct opposition to medieval Rus's social norms, which prescribe ultimate submission of women, either in marriage or a convent. Burning witches and wizards alive, as attempted by Dmitrii with Vasya, was part of old-Russian legislation (Lukyanov 2017: 65). Fantasy here is not in burning but in rescue. The only other woman in the trilogy, who succeeds in escaping marriage and a nunnery, is Varvara, Tamara's non-magical twin-sister. Knowledgeable but without magical powers, she nevertheless inherits from her father Chernomor an inhumanly long lifespan, which in alternative Slavic fantasy signals wizardry (Fialkova 2020: 444, 453). Age is what differentiates her from Rowling's squibs (a non-magical person born to at least one magical parent) ${ }^{35}$ whom she otherwise resembles. Varvara chooses life as a maidservant in the home of her kin, because low status gives a woman more freedom than married life as a noble lady.

Inheritance of magical power is not only uneven in Arden's trilogy but also has contrasting centres of attraction. For Vasya these are chyerti - devils, or more precisely, pagan spirits. They are both traditional (e.g., domovoi (house spirit), dvorovoi (dooryard spirit), polevik (field spirit) and bannik (bathhouse spirit)) and invented, such as the bagiennik (swamp spirit) and vazila ${ }^{36}$ (horse guardian spirit) (Arden 2017: 47, 85-86, 88, 90; 2019: 112). Vasya's brother, Sasha, devotes himself to Christianity and the Christian God. This divergence results not in animosity between them but rather in a pooling of the two resources to defend Rus against Mamai. Sasha becomes a monk-warrior and the hero of single combat with the Tatar warrior Chelubey ${ }^{37}$ before the Battle of Kulikovo. Although it results in the instant death of both, Russians choose to perceive it as a good omen. Sasha's full name as a monk, Alexander Peresvet (Lightbringer), is well known from the historical records, for example, Skazanie o Mamaevom poboishche [The Tale of the Rout of Mamai] from the first quarter of the 15 ${ }^{\text {th }}$ century (Skazanie 1981: 175-177, 184-185). Alexander Peresvet was later canonised by the Russian Orthodox Church

\footnotetext{
35 Squib https://harrypotter.fandom.com/wiki/Squib (last accessed 12.11.2020).

${ }^{36}$ Vazila was invented by P.M. Shpilevskii who signed his paper with the pen-name Drevlianskii (Toporkov 2002: 247). It is unclear whether Arden was aware about their quasi-folklore characters or took them for granted. Transliterated Russian words are not italicised in the text. - L.F.

37 The Mongol-Tatar combatant's real name was Temir-Murza or Tavrulum, but Arden calls him Chelubey, as typical in Russian sources (Galeotti 2019: 60).
} 
(Andronik 2007: 532-533). ${ }^{38}$ Although Arden's choice of making Vasya/Vasilisa a witch and Sasha/Alexander a monk is historically possible, it is one that is more typical of Western than Russian perception of gender role distribution. Contrary to Western countries, where witchcraft was mostly in the female domain, in Russia male wizards formed a majority (Kivelson 2013: 83, 124, 126). ${ }^{39}$

Arden prefers leaving the main events and actors of Russian history unaltered. The changes, when they occur, result from existing but aggravated facts and tendencies. A good case in point is the controversial figure of Prince Oleg of Ryazan. While many historical sources (especially those of Moscovite origin) perceive him as a traitor who supported Mamai in the Battle of Kulikovo, others (especially those originating from Ryazan and later historians) find him guiltless (Galeotti 2019: 22; Denisova 2012: 1-2). An important source here is Zadonshchina, the late $14^{\text {th }}$-century Russian literary monument, and its account of seventy Ryazan boyars who perished in battle fighting for the Russians. The mere fact that this is a larger number than from any other principality cited indicates they at least could have Oleg's permission to fight on Dmitrii's side (Zadonshchina 1981: 110-111). Arden goes further. Although her Oleg is initially in Mamai's camp, he not only saves Vasya from Chelubey but lets her convince him to fight under Dmitrii (Arden 2019: 297-298, 344-345). Another example concerns Alexander Peresvet. While the Russians simply chose to perceive him as the victor, Arden grants Sasha the final lunge of his dagger into Chelubey's throat (Arden 2019: 335; Galeotti 2019: 60).

Arden's main strategy, however, is adding layers that are 'missing in written records'. In her book, Moscovites suffer from plague as they did in reality; however, Arden's plague is unleashed by the Bear, who deliberately infects the cathedral's vast congregation when he makes them kiss the icon he uses for the dead (Arden 2019: 181-182). The battle with Mamai is indeed a consequence of unpaid tribute to Tatars, but, in Arden's version, Vladimir Andreevich fails to deliver the silver because vodyanoy sinks it into the water, on the Bear's instructions (Arden 2019: 128-132). Alexander Peresvet, about whom nothing is known other than that he is a monk of boyar origin and an adherent of Sergius of Radonezh (Radonezhsky), ${ }^{40}$ acquires a number of ancestors and relatives, including the folklore and literary characters Baba Yaga and Chernomor. The Russians win the battle but, to do so, they need not only unite their troops and rely on God's help but also ensure the coexistence of Christianity with pagan sprits. It is this treaty that Vasya succeeds in getting from Dmitrii and Father Sergei Radonezhsky of Trinity Lavra (Arden 2019: 186-187, 303-304). In The Tale of the Rout of Mamai, the boyar warrior Dmitrii

\footnotetext{
${ }^{38}$ In Lada Lusina's Kiev's Witches, three female protagonists must prove they descend either from witches or from saints in order to survive. To my mind, both types of ancestor may be found even within one family (Fialkova 2012: 215-216).

39 Although Kivelson addresses the later period (the $17^{\text {th }}$ century) her analyses are also applicable to earlier Russian history.

${ }^{40}$ Saint Sergius of Radonezh, born as Barfolomey (1314-1392), founded Trinity Lavra (https://www.britannica.com/biography/Saint-Sergius-of-Radonezh (last accessed 12.12.2020). He prayed for a Russian victory in the Battle of Kulikovo and sent Dmitrii his blessings. Arden usually calls him Sergei, Father Sergei or Sergei Radonezhsky, although she is acquainted with the form Sergius used by the Church (Arden 2017: 41, 2019: 186, 191, 202, 359; Skazanie o Mamaevom poboishche, 173).
} 
Bobrok Volhynian uses paganism to predict the outcome of the Battle of Kulikovo. He listens to the earth and hears wolves and swans, rumbling mountains and the wailing of Tatar women. As, according historical sources, Nature itself participates in the battle, why not believe that it included its supernatural lords: the Bear and Morozko? (Skazanie 1981: 167-171; Arden 2019: 311). Most of what Arden's characters do connects with the hidden supernatural mechanism of history without impacting known, actual outcomes of events. Her fantasy can thus be defined as crypto-history rather than alternative history.

TO BE CONTINUED IN STUDIA MYTHOLOGICAL SLAVICA, 2022

\section{MEDIEVAL SOURCES:}

Lavrentievskaia letopis'. Polnoe sobranie russkikh letopisei. T. 1. 1926-1928. Leningrad: Izdatel'stvo Akademii nauk SSSR., 332-334.

Novgorodskaia pervaia letopis' mladshego izvoda. Polnoe sobranie russkikh letopisei. T. 3. 1950. Moskva-Leningrad: Izdatel'stvo Akademii auk SSSR. http://yakov.works/acts/12/pvl/ novg24.htm (last accessed 12.09. 2020).

Skazanie o Mamaevom poboishche. 1981[first quarter of the $15^{\text {th }}$ century]: In" L.A. Dmitriev, D.S. Likhachev (Eds.) Pamiatniki literatury drevnei Rusi. XIV-seredina XV veka. Moskva: Khudozhestvennaia literature, 132-189.

Zadonshchina, 1981 [end of the $14^{\text {th }}$ Century] In: Dmitriev, L.A., Likhachev, D.S. (Eds.) Pamiatniki literatury drevnei Rusi. XIV- seredina XV veka. Moskva: Khudozhestvennaia literature, 96-111.

\section{BIBLIOGRAPHY}

Afanasev, A.N., 1916: Russian Folk-Tales. Translated from Russian Leonard A. Magnus. London: E.P. Dutton and Co, 78-91, 192-203. http://www.gutenberg.org/files/62509/62509-h/62509-h. $\mathrm{htm}$ (last accessed 25.09.2020).

Afanasiev, A.N., 1984: Russkie narodnye skazki v 3-kh tomakh. T.1. Moskva: Nauka.

Alici, Mustafa, 2011: The Idea of God in Ancient Turkish Religion According to Raffaele Pettazzoni. SMSR 77(1), 137-154.

Andronik, igumen. 2007: Aleksandr (Peresvet) I Andrei (Osliabia) Radonezhskie. Pravoslavnaia entsiklopedia, T.1, 532-533. https://www.pravenc.ru/text/64384.html (last accessed 15.11.2020).

Arden, Katherine, 2017: The Bear and the Nightingale. New York: Del Rey.

Arden, Katherine, 2018: The Girl in the Tower. New York: Del Rey.

Arden, Katherine, 2019: The Winter of the Witch. New York: Del Rey.

Bailey, James, Ivanova,Tatiana, 1998: An Anthology of Russian Folk Epics. New York: Routledge.

Borisov, Nikolai, 2005: Ivan Kalita. Moskva: Molodaia gvardia. https://royallib.com/read/borisov_nikolay/ivan_kalita.html\#1101269 (last accessed 10.10.2020).

Card, Orson Scott, 1999: Enchantment. New York: The Ballantine Publishing Group. 
Cherryh, C.J., 1989: Rusalka. New York: Del Rey.

Dalkesen, Nilgün, 2017: Cult of Alan-Gho'a and the Unique Position of Women in the Chinggisid Dynasties. AVRASYA Uluslararası Araştırmalar Dergisi, 5(10), 191-201.

Denisova, I.V. 2012: Letopisnyi mif ob Olege Riazanskom ("Povest' o nashestvii Tokhtamysha"). Vestnik riazanskogo universiteta 4(37), 1-8.

Dubeniuk, Nikolai. 2019: Voinskaia elita: istoria russkoi gvardii. Istoria.RF. https://histrf.ru/biblioteka/b/voinskaia-elita-istoriia-russkoi-ghvardii (last accessed 23.03.2021).

Ekzempliarskii, A.V., 1889: Ivan Danilovich Kalita. In: A.V. Ekzempliarskii. Velikie i udel'nye kniazia Severnoi Rusi v Tatarskii period s 1238 po 1505 g., T. 1. Sank-Peterburg: Tipografia Imperatorskoi Akademii Nauk, 71-79. https://runivers.ru/bookreader/book9597/\#page/83/ mode/lup (last accessed 10.10.2020).

Fialkova, Larisa, 2012: Printsipy sozdania fantasticheskogo obraza v romannom seriale Lady Luzinoi “Kievskie ved'my". In: Dejan Ajdacic (ed.), Slov'ians 'ka fantastika: zbirnyk naukovykh prats'. Kyiv: Kyivs'kyi universytet, 210-220.

Fialkova, Larisa, 2020: Al'ternativnoe slavianskoe fentezi amerikanskikh pisatelei. In: Дејан Ајдачић, Бошко Сувајџић (Уредници). Савремена Српска Фолклористика, VIII. Зборник радова. Словенски фолклор и къижевна фантастика. Београд - Тршић: Удружење фолклориста Србије, Комисија за фолклористику Међународног комитета слависта, 439-459.

Galeotti, Mark, 2019: Kulikovo 1380: The Battle that made Russia. Bloomsbury Publishing.

Granik, Anatolii, 1972: Dvenadtsat'mesiatsev. Dvukhseriinyi tsvetnoi televizionnyi fil'm-skazka. Kinostudia “Lenfil'm".

Harkins, William E., 1976: Boasting in the Russian Byliny. Journal of the Folklore Institute 13(2): $155-171$.

Homer. No Year. Iliad, Book 11. https://www.theoi.com/Text/Homerlliad11.html (last accessed 29.09.2020).

Ivanits, Linda, 1992: Russian Folk Belief. Armonk, New York, London: M.E. Sharp, Inc.

Ivanov-Vano, Ivan, 1956: Dvenadtsat'mesiatsev. Soizmul'tfilm. Vosstanovlen in 1987 na kinostudii im. A.M. Gor'kogo. English subtitles. https://www.culture.ru/movies/8223/dvenadcat-mesyacev (last accessed 12.10.2010).

Kitzen, Karlijn, 2019: Taking the Reader "Someplace a Little Different": Russian-ness in Young Adult Fantasy. MA Thesis European Literature. Radboud University Nijmegen. https:// clck.ru/MGWxL (last accessed 21.02.2020).

Kivelson, Valerie Ann, 2013: Desperate Magic: The Moral Economy of Witchcraft in Seventeenth Century Russia. Ithaca, London: Cornell University Press.

Krivosheev, Yu. V., Sokolov, R.A., 2012: Politika Aleksandra Nevskogo v Baltiisko-Skandinavskom regione. Trudy kafedry istorii Rossii s drevneishikh vremien do XX veka: kafedra istorii Rossii i sovremennaia nauka. Sankt-Peterburg: Sankt-Peterburgskii universitet, 265-295.

Leskov, Nikolai. No Year: O dvenadtsati mesiatsakh: clavianskoe predanie iz okrestnostei trenchinskikh Bozhiny Nemstovoi. https://www.litmir.me/br/?b=114021\&p=1 (last accessed 5.12.2020).

Longworth, Philip. 1970: The Cossacks. New York, Chicago, San Francisco: Holt, Rinehart and Winston.

Lukyanov, Sergey A., 2017: Koldovstvo kak vid religioznogo prestuplenia v drevnerusskom zakonodatel'stve. Sotsial'no-politicheskie nauki 4, 64-69. https://cyberleninka.ru/article/n/ koldovstvo-kak-vid-religioznogo-prestupleniya-v-drevnerusskom-zakonodatelstve/viewer (last accessed 31.10.2020). 
Marshak, Samuil, 1958: Dvenadtsat' mesiatsev. In: Samuil Marshak, Sochinenia v chetyriekh tomakh. T. 2. Lirika, povesti v stikhakh, satira, piesy. Moskva: Gosudarstvennoe izdatel'stvo izdatel'stva khudozhestvennoi literatury, 351-480.

Marshak, Samuil, 2000: Twelve Months: A Fairy Tale. Fredonia Books.

Martin, Janet, 2007: Medieval Russia. Cambridge: Cambridge University Press.

Morwood, Peter, 2016: Prince Ivan. Tales of Old Russia. No place: Venture Press.

Morwood, Peter, 2016a: Firebird. Tales of Old Russia. Book Two. No place: Venture Press.

Morwood, Peter, 2016b: The Golden Hord. Tales of Old Russia. Book Three. No place: Venture Press.

Němcová, Božena, No Year: The Twelve Months. Museum Boženy Němcové https://www.muzeumbn. cz/en-work-twelve-months/ (last accessed 12.10.2020).

Papakonstantonou, Zinon, 2009: Wine and Wine-drinking in the Homeric World. L'Antiquité Classique 78: 1-24. https://www.persee.fr/doc/antiq_0770-2817_2009_num_78_1_3735 (last accessed 29.09.2020).

Prokhorov, G.M., 1988: Aleksei (Aleksii), mitropolit vseia Rusi. Slovar'knizhnikov i knizhnosti Drevnei Rusi. Vyp. 2, Ch. 1. Leningrad. https://clck.ru/RL9rw (last accessed 11.10.2020).

Propp, Vladimir, 2012: The Russian Folktale. Editor and Translator Sibelan Forrester. Detroit: Wayne State University Press.

Pushkin, Alexander, 1978 [1831]: The Tale of Tsar Saltan, of His Son the Glorious and Mighty Knight Prince Gvidon Saltanovich, and the Fair Sawn-Princess. Translated by Louis Zellikoff. Moscow: Progress Publishers. https://ruverses.com/alexander-pushkin/the-taleof-tsar-saltan/7696/ (last accessed 12.10.2020).

Remizov, Aleksei, 2000: Korochun. In: Aleksei Remizov, Sobranie sochinenii v 10-ti tomakh. Tom 2. Moskva: Russkaia kniga. Moskva: Mezhdunarodnye otnoshenia.. https://ruslit. traumlibrary.net/book/remizov-ss 10-02/remizov-ss10-02.html\#s001001005001 (last accessed 15.10.2020).

Shcherbak, A.M., 1993: On the Chief Totem of the Ancient Turks. Türk Dilleri Araştırmaları 3: 203-211.

Selart, Anti, 2015: Livonia, Rus' and the Baltic Crusades in the Thirteenth Century. Translated by Fiona Robb. Leiden, Boston: Brill.

Senne, Katia, 2017: Staraia novaia skazka: mifopoeticheskii podtekst piesy-skazki S. Marshaka "Dvenadtsat' mesiatsev". Detskie chtenia https://cyberleninka.ru/article/n/staraya-novaya-skazka-mifopoeticheskiy-podtekst-piesy-skazki-s-marshaka-dvenadtsat-mesyatsev/ viewer (last accessed 19.03.2021).

Seward, Desmond, 1995: The Crusade on the Baltic. In: Desmond Seward, The Monks of War: The Military Religious Orders. Penguin Books, 95-109.

Skye, Evelyn, 2016: The Crown's Game. New York: Balzer + Bray, An Imprint of HarperCollins Publishers.

Skye, Evelyn, 2017: The Crown's Fate. Balzer + Bray, An Imprint of HarperCollins Publishers.

Tolstoi, N.I., 1995: Belyi bog. In: N.I. Tolstoi (Ed.) Slavianskie drevnosti: etnolingvisticheskii slovar'. T. 1. Moskva: Mezhdunarodnye otnoshenia.

Toporkov, A.L., 2002: O "Belorusskikh narodnykh predaniakh i ikh avtore. In: A.L. Toporkov et al. (ed.), Russkaia potaennaia literature: rukopisi, kotorykh ne bylo. Moskva: Ladomir, 245-254.

Trocha, Bogdan, 2020: Renarracje Słowiańskich motywów Ludowych we współczesnej fantastyce. Дејан Ајдачић, Бошко Сувајџић (Ур.). Савремена Српска Фолклористика, VIII. 
Зборник радова. Словенски фолклор и књижевна фантастика. Београд - Тршић: Удружење фолклориста Србије, Комисија за фолклористику Међународног комитета слависта, 401-417.

Valente, Catherynne M., 2011: Deathless. New York: A Tom Doherty Associates Book. http://www.arvindguptatoys.com/arvindgupta/65r.pdf (last checked 11.10.2020).

Valentsova, Marina M., 1999: Karachun. In: N.I. Tolstoi (ed.), Slavianskie drevnosti: etnolingvisticheskii slovar', T. 2. Moskva: Mezhdunarodnye otnoshenia. 468-469.

Zheleznova, Irina (ed.), 1966: Father Frost. In Vasilisa the Beautiful. Russian Fairy Tales. Translated by Irina Zheleznova Moscow: Progress publishers.

\section{РУСЬ, РОССИЯ И УКРАИНА В АЛЬТЕРНАТИВНОМ СЛАВЯНСКОМ ФЭНТЕЗИ АНГЛОЯЗЫЧНЫХ ПИСАТЕЛЕЙ. ЧАСТЬ 1. СРЕДНЕВЕКОВАЯ РУСЬ. ЛАРИСА ФИАЛКОВА $\infty$}

Термин альтернативная славянская фантастика определяет англоязычное фэнтези, сюжеты которого развиваются в славянских или квазиславянских странах на базе славянского или квазиславянского фольклора. В отличие от первой публикации автора по этой теме (2020), в которой речь шла о внеисторических сюжетах в мифологическом пространстве, предметом данной двухчастной статьи является историческое фэнтези. Первая часть посвящена условному средневековью от Киевской Руси до Куликовской битвы в трилогиях Питера Морвуда и Кэтрин Арден. У обоих писателей исторические события и персонажи слиты с сюжетами и персонажами быличек и волшебных сказок, фольклорных и литературных. Фольклор является частью образования персонажей, - из письменных источников у Морвуда и из традиционной устной трансмиссии у Арден. Морвуд рассматривает фольклорные и исторические источники как потенциально равноправные, поскольку княжеские манипуляции хрониками, лишили их статуса документа. Такой подход позволяет комбинировать различные исторические события, например, малое ледовое побоище 1234 года с Невской битвой 1240-го года и Ледовым побоищем 1242-го года. Аналогичным образом чудесная помощь христианских сил - Бога или, скажем, святых Бориса и Глеба, упомянутая в летописях, легко заменяется помощью волшебных помощников - Жар-птицы и Серого волка. В созданном Морвудом мире язычество относительно мирно сосуществует с христианством, поскольку правители и псевдоисторические, и сказочные, например, Марья Моревна, умело сдерживают давление церковников. 
В отличие от Морвуда, Арден в целом следует исторической канве. Ее стратегия - дописывать "факты", якобы опущенные в письменных источниках и предлагать "подлинные" причины тех или иных событий. Подобно историкам, Арден называет неуплату дани татарам поводом для Куликовской битвы, но причиной неуплаты у нее становятся действия водяного, потопившего серебро по приказу Медведя. История умалчивает о родословном древе монаха и боярского сына Александра Пересвета, известного поединком с Челубеем перед Куликовской битвой, впоследствии канонизированного. Отсутствие известных предков позволяет объявить ими Черномора и Бабу Ягу, заодно придав в сестры монаху-воину андрогинную ведьму Василису. Родство Александра и Василисы облегчает примирение враждующих христианских и языческих сил, необходимое для победы Руси в Куликовской битве и в дальнейшем противостоянии врагам. Изменения, вносимые Арден, не влияют на результаты событий, а лишь обнаруживают их скрытые причины. Речь идет не столько об альтернативной истории, сколько о крипто истории.

Вторая часть статьи, посвященная сюжетам нового и новейшего времени, будет опубликована в следующем номере журнала.

Prof. Dr. Larisa Fialkova, Department of Hebrew and Comparative Literature, University of Haifa, Abba Khoushy Ave 199, Haifa, Israel, lara@research.haifa.ac.il 